\title{
Cinqüenta anos da Revista Brasileira de Reumatologia
}

1 sorte, às vezes, bate à nossa porta. Creio que podemos dizer que quis o destino dar-nos a oportunidade de estar na Editoria da RBR no ano em que completa seus 50 anos.

Todos sabemos da efemeridade de várias iniciativas, particularmente no nosso país. Estamos acostumados a decisões serem anunciadas como já se tratasse de medidas implementadas, quando na verdade se trata de intenções, se muito, mormente na esfera do poder público. Felizmente, ante a iniciativa dos pioneiros da Reumatologia Brasileira, pôde ser escolhido um momento adequado para o lançamento da revista. Essa conclusão baseia-se no simples fato de que vingou a RBR, agora já nos seus 50 anos, para orgulho e exemplo da reumatologia brasileira à nossa sociedade. Essa é uma demonstração da correção da primeira decisão, resultado do trabalho encabeçado pelos primeiros editores, como bem nos conta Prof. Hilton Seda, em outro Editorial neste número.

Uma vantagem de estarmos na editoria é o fato de termos acesso aos textos escritos pelos colegas convidados a celebrar os 50 anos da RBR. Difícil escolher a quem pedir textos, pois não haveria espaço para todos com competência para abrilhantar essa edição comemorativa. Esperamos que todos se sintam bem representados pelos autores escolhidos. Não faltará, asseguramos-lhes, espaço para manifestações em cartas ao editor, em edições subseqüentes, de colegas que desejem contribuir com reflexões sobre esse momento festivo da RBR. As rotativas, ou seja, as impressoras, estão abertas.

Em todo momento de celebração, entretanto, cabe reflexão sobre o trabalho feito, a avaliação do que se tem e os projetos futuros. Fiquemos nos projetos futuros, posto que necessariamente somos otimistas com a nossa RBR e a classe.

Comecemos por informar que essa última indexação ao Medline, tentada pelos editores que nos precederam, a que se refere Prof. Luis Eduardo Andrade em texto neste número comemorativo, não logrou êxito. Cabe agora perguntar, como nos admoesta Prof. Andrade. Chega de tentar? O nosso destino é ter um periódico local praticamente restrito ao país? Ou será que vale a pena insistir e re-submeter?

Por nossa parte, dir-lhe-íamos: não há motivo para desistir da indexação. Há que nos debruçarmos sobre os motivos (baixa prioridade pelo conteúdo científico, língua predominante, articulação política...) e desenvolvermos um projeto para vencer essa etapa.
Estando na editoria, teoricamente alguém mais apressado e certamente menos informado sobre as dificuldades da RBR poderia nos inquirir que não nos cabe perguntar, mas, como disse há pouco um certo ministro: "Façam ou caiam fora”. Se essa expressão pareceu intempestiva quando de tão grave momento por que passa a administração pública nesse país, pensamos que algo similar ocorra conosco. Não haverá receitas mágicas nem rápidas. Planejamento estratégico e trabalho árduo e conjunto, em uma união de esforços de todos os reumatologistas, nos parecem fundamentais para alcançar esse objetivo. Nessa premissa, sugerimos à nossa comunidade científica que criemos um grupo de trabalho para desenvolver o projeto de melhoria técnica da RBR. Esse grupo, de cuja composição o corpo editorial poderia se incumbir, deveria ser pequeno o suficiente para ter agilidade, mas aberto à recepção de sugestões. $\mathrm{O}$ estabelecimento de um cronograma de trabalho, com metas a serem cumpridas dentro de prazos estabelecidos, seria o passo inicial, com a coordenação da Diretoria da SBR, representada por seu Presidente, tendo-se um membro do Conselho Editorial como Diretor Executivo. O resultado desse trabalho seria discutido durante um dos Eventos da SBR, com prévia disponibilização a todos os interessados do conteúdo a ser discutido. Acreditamos que modificações no Conselho Editorial serão necessárias e a compreensão de alguns colegas sobre a permanência ou ingresso nesse corpo será importante, uma vez se tratar de grupo renovável periodicamente.

Consultar colegas editores de publicações nacionais que já conseguiram a indexação por nós sonhada pode nos ajudar nesse projeto. Como exemplo, o Brazilian Journal of Medical and Biological Research acaba de alcançar impacto acima de 1.0 .

Nesse momento de alegria pelos festejos dos seus 50 anos, só temos a oferecer o nosso interesse em trabalhar pela RBR e a nossa disposição de contribuir para que os que irão suceder-nos em 2008 encontrem um caminho iniciado para a inserção definitiva da RBR no rol dos periódicos com indexação ampla.
Francisco Airton Castro da Rocha Ricardo Machado Xavier Editores 